\section{Managers' leadership style and the commitment of their team members: associating concepts in search of possible relations}

\author{
Priscila Lopes da Silva ${ }^{1}$ \\ Simone Costa Nunes ${ }^{1}$ \\ ${ }^{1}$ Pontifical Catholic University of Minas Gerais, Postgraduate \\ Program in Administration, Belo Horizonte, Brazil \\ Darly Fernando Andrade ${ }^{2}$ \\ ${ }^{2}$ Federal University of Uberlândia, Faculty of Management and Business, \\ Department of Methods and Information, Uberlândia, Brazil
}

\begin{abstract}
Purpose - The aim of the research was to investigate how managers' leadership styles interfere with the commitment of their team members. Five hypotheses were tested in order to identify relationships between the leadership style and the components of the commitment.

Design/methodology/approach - The method chosen was quantitative and a survey was conducted. The data were collected through the application of two questionnaires. A total of 587 questionnaires were considered valid. Descriptive statistics, CHAID analysis and Pearson's correlation were used in the analysis.
\end{abstract}

Findings - The correlation between the managers' leadership styles with relationship orientation and the affiliate component of commitment was significant; there is a positive relationship between the task orientation and the normative commitment; there is a positive relation between situational leadership style and affective commitment, as well as between this style and the general commitment.

Originality/value - This study contributes to the debate about the existence of a relationship between some components of commitment and leadership styles, pointing out how the leadership style can affect the type of commitment of the team members, specifically regarding the positive relation between the situational leadership style and the general commitment; the relationship orientation and the affiliate component; and the task orientation and normative component.

Keywords - Commitment; Leadership styles; Leadership.
Received on

05/10/2017

Approved on

10/22/2018

Responsible editor:

Profa. Dra. Gina Gaio Santos

Evaluation process:

Double Blind Review

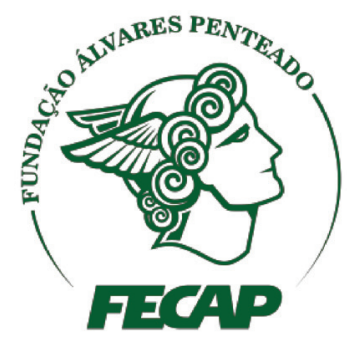

Review of Business Management 


\section{Introduction}

This work is the result of research intended to identify how managers' leadership styles influence the commitment of their team members.

Studies such as de Sá and Lemoine (1998) and Bycio, Hackett and Allen (1995) show that leadership style influences the organizational commitment of individuals. High levels of commitment, according to Royal (2012), are not sustainable without working conditions that support the employee. In order to keep them committed over time it is necessary that they can rely on the organization's support for two main elements: optimized functions and an environment of support. In both, there is direct action from managers.

Considering that the contemporary competitive environment of organizations has led to the understanding that their employees are their most valuable assets, leadership and commitment are being identified as the key assets of high performance organizations (Yozgat, Serim \& Dikmen, 2014).

There are, in the literature, studies that relate the organizational commitment and leadership themes. The work by Weaver and Yancey (2010), Mehta and Maheshwari (2013), Yozgat et al. (2014), and Colbert, Barrick and Bradley (2014) are examples. However, in Brazil, specifically in the area of Public Administration and in Business, Accounting, and Tourism, whose journals classified in the Qualis/Capes are found in the SPELL electronic library collection, there are few studies done on these themes together.

Research conducted on this basis pointed to the existence of only six articles that combine in their titles the terms commitment and leadership or commitment and leader, one of which uses the term leader to refer to companies, not managers. Thus, the five articles related to the theme are: Marques, Medeiros, França and Ribeiro (2007), Maciel and Nascimento (2013), Fernandes, Siqueira and Vieira (2014), Nogueira, Costa and Claro (2015), and Zanini, Santos and
Lima (2015). However, none of them presents the perspective adopted in this study involving, simultaneously, the three styles of leadership present in the Leadership Style Assessment Scale $(E A E G)$ and the seven components of commitment, according to the Organizational Commitment Scale (EBACO).

Thus, it is understood that this study, unlike the few already published in Brazil establishing the relationship between the two themes, allows us to associate the commitment construct with the styles that, as Melo (2004) argues, permeate most research on leadership: relationship, task, and situation.

In view of the above, this raised interest in answering the following question: What are the relationships between leadership styles and organizational commitment?

In order to address the proposal of this study, the following specific objectives were outlined: to determine the level of commitment of team members; to look for correlations between the level of commitment of team members and the profile of the sample; to identify managers' leadership styles; to look for correlations between managers' leadership styles and the profile of the sample; to analyze the correlation between commitment (team members) and leadership style (managers).

The study contributes to the literature indicating the positive relationship between the leadership styles adopted and some of the components of commitment, with the following results being positive: situational leadership style and general commitment; relationship-oriented leadership style and the affiliate component; and task-oriented leadership style and the normative component.

The relevance of the results is supported by Balci (2003), for whom employees with a higher level of commitment tend to contribute more to organizational goals, being more productive, handling more work responsibilities, and being more loyal and satisfied, directly affecting organizational results. In addition, and 
in agreement with Leite (2008), and Leite and Albuquerque (2011), managers, in exercising a direct influence on the process of gaining commitment, help maintain a cooperative/ relational psychological contract, with the development of solidarity, and sustained by values that help create organizational identity, increase commitment, and bring people together.

\section{Organizational Commitment}

Organizational commitment came to be investigated more frequently based on the work of Mowday, Porter and Steers (1982). In Brazil, it was in the 1990s that research focused on the theme was consolidated, with the pioneering works of Borges-Andrade, Cameschi and Silva (1990), and Bastos (1993). Some examples of recently published studies on the subject are: Silva, Leite and Rodrigues (2016); Cappi and Araújo (2015); Cardozo, Araújo and Silva (2015); Marques, Borges, Morais and Silva (2014); Oliveira, Cabral, Pessoa, Santos and Roldan (2014); Maciel and Nascimento (2013), and Lemos, Cavazotte and Nogueira (2012).

Beginning in the 1990s, commitment began to be studied as a multidimensional phenomenon, and studies were developed using the idea that there always exists more than one focus on organizational commitment. This vision of Meyer and Allen is, according to Medeiros, Albuquerque, Marques and Siqueira (2005), the one that best summarizes this perspective in calling these aspects or dimensions of the components of commitment, namely: affective - denotes the employee's identification and involvement with a given organization; instrumental - associated with the amount of loss with the employee's exit from the company; normative - denotes the employee's willingness to remain in the organization by virtue of a sense of moral obligation to it.

Using as references the work by O'Reilly and Chatman (1986), Meyer, Allen and Smith (1993), as well as others that also contributed indicators not found in these two studies, Medeiros (2003) carried out research that pointed to seven components of organizational commitment. These compose the Organizational Commitment Scale $(E B A C O)$, validated and intended for the Brazilian context, whose components and indicators are presented below, in Table 1:

Table 1

\section{Components and indicators of organizational commitment - EBACO}

\begin{tabular}{ll}
\hline Component & Indicator \\
\hline $\begin{array}{l}\text { Affective } \\
\text { (Internalization of values and }\end{array}$ & - Since joining this organization, my personal and organizational values have become more similar \\
objectives) & - I identify with the philosophy of this organization \\
& - I believe in the values and objectives of this organization \\
& - The reason I prefer this organization over others is because of what it symbolizes, its values \\
\hline Instrumental & - I think I would have few alternatives if I left this organization \\
(Limited alternatives) & - If I decided to leave my organization now, my life would become quite unstructured \\
& - One of the few negative consequences of leaving this organization would be the scarcity of \\
& immediate alternatives \\
& - I would not leave this job now because of the lack of job opportunities \\
\hline Instrumental & - I try not to break the rules here, because this way I will always keep my job \\
(Consistent lines of activity) & - In the current situation, staying with my organization is in fact a necessity as much as a desire \\
& - To be rewarded here it is necessary to express the right attitude \\
& - I will always do my best in my work to keep myself in this job. \\
\hline
\end{tabular}




\begin{tabular}{ll}
\hline Component & Indicator \\
\hline $\begin{array}{l}\text { Instrumental } \\
\text { (Rewards and opportunities) }\end{array}$ & - If I had not already given so much of myself to this organization, I might consider working \\
& elsewhere \\
& - Unless I am rewarded in some way, I see no reason to spend extra effort to benefit this organization \\
& - My personal view about this organization is different from the one I express publicly \\
& - Despite the efforts I've already made, I do not see opportunities for me in this company \\
\hline Normative & - Even if it was to my advantage, I feel it would not be right to leave my organization now \\
(Obligation to remain) & - I would not leave my organization now because I have a moral obligation to the people here \\
& - I would feel guilty if I left my organization now \\
& - I believe that it would not be right to leave my organization because I have a moral obligation to \\
& remain \\
\hline $\begin{array}{l}\text { Normative } \\
\text { (Obligation for performance) }\end{array}$ & - Every employee should try to achieve the company's objectives \\
& - The good employee must strive for the company to have the best results possible \\
& - I have an obligation to perform well in my job at the company \\
& - Employees have the obligation to always carry out their jobs. \\
\hline Affiliate & - I feel that my colleagues consider me a member of the work team \\
(Feeling of being part) & - In this company, I feel that I am part of the group \\
& - I am recognized by everyone in the company as a member of the group \\
& - Being part of the group is what drives me to fight for this company
\end{tabular}

Note: Adapted from Medeiros (2003) and Medeiros et al. (2005).

In the model by Medeiros et al. (2005), from which came the $E B A C O$, the instrumental component was divided into three parts (existence of few alternatives; imbalance in the relation between rewards and contributions; and feeling of engagement in consistent lines of activity). And the normative was divided into two parts (obligation to remain and obligation to achieve the organization's objectives).

There is a wide range of studies on this topic. In addition to those already mentioned, some others will be highlighted, taking into account their contribution to the analysis of the results found in the present study. Although Meyer, Stanley, Herscovitch and Topolnytsky (2002) understand that the correlations between commitment and personal characteristics tend to appear weak or even inconsistent, Honório and Ribeiro (2014) argue that a greater commitment can be associated with older individuals, those with more time in the organization, a higher level job, better compensation. From this perspective, some of the results indicated in the literature follow.

The study by Yoshitake, Fraga, Torres and Passos (2009) found that, in the case of the affective component, the mean for the operational position was statistically different from the mean for the leadership position. Employees who do not hold a leadership position appear more affectively committed to the company than those who occupy such a position, in that study, the supervisory position. In contrast, Costa, Moraes and Cançado (2008) found that the instrumental component had a significant difference when it came to the position held, and those who did not hold a leadership position showed greater instrumental commitment, presenting higher means than the others. Those who held a leadership position, on the other hand, demonstrated greater commitment of the affective type.

Martins (2013) points out that normative commitment is more significant in the age groups between 36-40 years and 51-55 years. The other ranges show reduced variation, despite the noted tendency of normative commitment to be higher in the more advanced age groups. In this regard, Nawaz and Kundi (2010) point out that as one ages, one's sense of obligations also gains maturity. In addition, the opportunities for change decrease. As a result, older people have greater organizational commitment compared to younger people. The study by Suri and Petchsawang (2018) corroborates this view, finding as a result the greatest commitment in those who are 50 or older.

Other works also found similar results. Bandeira (1999) shows that older people, over 35 years of age, are more committed, in agreement 
with Bastos (1993) and Honório and Ribeiro (2014), who also argue that commitment increases with age. In addition, Chang's (2001) study shows that the older the employee, the greater the pride of belonging. In this case, it is inferred that affective commitment should be greater.

Regarding years worked, Honório and Ribeiro (2014) indicate that length of service is significantly associated with the commitment of the group of teachers who had worked less than six years at the institution, presenting greater organizational commitment than their peers with a greater length of service. The study by Suri and Petchsawang (2018), on the other hand, points out that the level of organizational commitment increases as employees progress in their positions and move up the hierarchy, gain more experience, and spend more time in their organizations. Thus, position and years of experience are positively related to commitment.

Costa, Moraes and Cançado (2008), in contrast, suggest that there is no significant relationship between commitment and length of service in the company. Similarly, research by Akintayo (2010) revealed that there is no significant difference in organizational commitment between participants with more than 10 years of work experience and those with less than 10 years of experience.

With regard to having children, in the study by Martins (2013), a valid significance was identified for normative commitment in the case of those who have one child; it increases in the case of professionals who have two children and, from there, reduces as the number of children increases.

The decrease in commitment, in general, as the number of children increases, can be explained in Chang (2001). This author argues that the number of children is inversely associated with the pride of belonging, inferring that the larger the employee's family, the more they need to dedicate themselves to it, to the detriment of their devotion to the company that, specifically in the study by this author, required 14 to 15 hours of work per day. This view also appears in Akintayo (2010) who, having found less commitment among married people, associated that fact with maternal family responsibilities and with the work-family conflict experienced by married couples.

Regarding salaries, Martins (2013) points out that normative commitment presents a result with maximum value in the group with the highest salary range [monthly], in this case, between 8,001.00 and 9,000.00 Brazilian Reais [BRL]. Also, Costa, Moraes and Cançado (2008) note that those who receive more than two times the minimum wage demonstrated greater affective commitment than those who receive less than that. In addition to salary, Suri and Petchsawang (2018) add that commitment is also supported by other monetary benefits such as pension, funds, and allowances. In contrast, Seong, Hong and Park (2012) indicate that discrepancies in payment do not seem to fully explain the different levels of commitment in the research conducted with regular and non-regular contract workers, as well as between women and men.

With respect to academic training, Martins (2013) identified that there is a decrease in the level of affective and normative commitment in accordance with the increase in the level of education of the respondents. Only professionals with postdoctoral training elude this trend, exhibiting the highest level of commitment among the groups. In addition, the study by Honório and Ribeiro (2014) showed lower levels of commitment associated with higher levels of schooling. While the research by Suri and Petchsawang (2018) did not present sufficient evidence of the relationship between the commitment and the level of education of the respondents.

Considering gender, on the one hand, Sangmook (2005) points out that women present higher levels of involvement with employment. It has been suggested that this occurs because women value more the intrinsic factors associated with achievement at work, and because the female culture itself contributes to their higher levels of involvement, something that, according to the author, may stem from the inherent difficulties in their entering the job market. On the other hand, Akintayo (2010) identified a higher level of commitment among men. Nevertheless, the 
study by Seong, Hong and Park (2012) showed that, although male workers present a slightly higher score than women regarding organizational commitment, this difference is very small and not statistically significant, indicating that there is practically no overall difference by gender. This result is corroborated by the studies of AI-Ajmi (2006), Suki and Suki (2011), and Suri and Petchsawang (2018), who concluded that men and women have the same level of organizational commitment, with no significant relationship between gender and commitment having been found.

Moreover, regarding commitment in general terms, the research by Ricco (1998) shows that the affective component stands out in relation to the instrumental, which is practically null, while the normative component almost does not appear. On the other hand, Rego, Cunha and Souto (2007) note that, in relation to the instrumental component, when the strongest link is with this kind of commitment, employees do not usually give the organization anything more than they are obliged to, which can lead them to take on negative attitudes and actions, such as absenteeism and retaliation.

Finally, Khan, Khan, Khan, Nawaz and Yar (2013) call attention to the importance of considering that demographic characteristics have greater implications in the cases of poor or developing countries compared to advanced countries, with high educational levels and greater financial equality, among others. The authors argue that the groups differ in many respects and need to be understood in order to define the parameters with impact on the characteristics of an individual which lead to the development of organizational commitment.

\section{Leadership and Commitment}

The studies of the leader's personal traits, of leadership styles, of contingent leadership, new leadership, and team leadership are the main approaches to the leadership theme (Delfino, Silva, \& Rohde, 2010).

Given the diversity of conceptions, Bass argued that the search for a single definition of leadership was useless and that the definition depends on the specific aspect of leadership of interest to the individual (Bass, 2008). Nonetheless, common points can be observed, such as the view of leadership as a social process, which involves the interaction between leader and those being led, and aspects such as influence, relationships, and results.

Leadership can affect the behavior of an organization's employees regarding attitudes, motivation, and performance, all of which can affect levels of commitment. In this sense, leaders, in interaction with their teams, use a combination of characteristics, skills, and behaviors that are associated with leadership style. These are commonly based on the combination of their beliefs, ideas, norms, and values (Iqbal, Inayat, Ijaz, \& Zahid, 2012).

There is a certain understanding that companies, in order to retain their employees, need to guarantee commitment and job satisfaction (Steil, Penha \& Bonilla, 2016). Many factors can affect job satisfaction and feelings about organizational commitment. However, one of the most important factors is the leadership behavior of managers (Webb, 2011). By minimizing employees' intention to leave the organization, it is possible for them to feel committed to the business (Naqvi, Hashmi, Raza, Zeeshan, \& Shaikh, 2011).

As organizational commitment is fundamental to the organization, not only because it is related to the retention of people, but also to their engagement (Cole, Walter, Bedeian, \& O'Boyle, 2012), and as leadership theories emphasize that, in order to achieve the organization's desired results, leaders must create relationships with those they lead in order to stimulate their commitment (Saher, Naz, Tasleem, Naz, \& Kausar, 2013), a direct relationship between leadership and organizational commitment is clearly presented.

Among others, the study by Colbert, Barrick and Bradley (2014) shows that the transformational leadership of the direct leaders of employees had a greater impact on their commitment than the leadership of the CEO. This may indicate that leaders are especially important in fostering employee bonds with the organization. From this perspective, managers 
should consider efforts to build relationships with their direct subordinates as a fundamental part of their contribution to organizational effectiveness.

With respect to negative leadership behaviors, studies have shown that abusive leadership is inversely related to affective commitment and continuance (Rayner \& Cooper, 1997; Tepper, 2000). In turn, Mehta and Maheshwari (2013) affirm that there is an inverse relationship between leadership behaviors considered toxic and organizational commitment. This finding supports the conclusions of Weaver and Yancy (2010) that destructive leadership is inversely related to the affective commitment of employees and positively related to the intention to leave their organization.

Moss, McFarland, Ngu, \& Kijowska (2007) examined the impact of leadership style on the relationship between worker openness to experiment and their organizational commitment. The key question they covered was whether specific types of leadership (transformational, transactional, and laissez-faire) could have a positive effect on workers who have a high level of openness to experience. These authors have suggested that transformational leadership would positively reinforce the connection between employee openness and their organizational commitment.

The results of the study by Gilbert, Halliday, Heavey and Murphy (2011) indicate that trust strongly affects commitment and that motivation has a strong association with work performance. Like Morgan and Hunt (1994), they show a strong level of association between trust and commitment.

Although none of the studies and research presented earlier establish the specific relationship between commitment and the three leadership styles (relationship, task, and situation) tested in the present study, they all present some kind of relationship between the variables Leadership and Commitment.

Given the diverse framework of leadership approaches, Melo (2004) found that the manager's performance is centered on one of the following focal points: relationship, task, or situation. From the analysis of points of convergence in the theoretical field, this author established, for each factor, or leadership style, the conceptual field. The objective was to define the bases for elaboration of the Leadership Style Assessment Scale $(E A E G)$, whose dimensions and indicators are presented in Table 2:

Table 2

\section{Dimensions and Indicators of Leadership Style}

\begin{tabular}{|c|c|}
\hline Dimension & Indicator \\
\hline Relationship & $\begin{array}{l}\text { - Finds time to listen to group members } \\
\text { - Is considerate in the relationship with subordinates } \\
\text { - Is interested in the feelings of subordinates } \\
\text { - Demonstrates accessibility to subordinates } \\
\text { - Demonstrates respect for subordinate ideas } \\
\text { - Stimulates the presentation of new ideas at work } \\
\text { - Demonstrates confidence in subordinates } \\
\text { - Is understanding with the failures and mistakes of subordinates } \\
\text { - Encourages subordinates to give opinions about work }\end{array}$ \\
\hline Task & $\begin{array}{l}\text { - Values discipline and subordination (hierarchy) } \\
\text { - Values respect for authority } \\
\text { - Is rigid in complying with the established deadlines } \\
\text { - Asks that group members follow established norms and rules } \\
\text { - Puts work first } \\
\text { - Indicates to the members of the group the specific tasks of each }\end{array}$ \\
\hline Situational & $\begin{array}{l}\text { - Gives freedom of action to subordinates who are reliable for the task to be performed } \\
\text { - Gives the subordinate greater or lesser freedom of action, depending on his/her competence to perform the task } \\
\text { - Gives freedom of action to subordinates who are motivated to perform the task } \\
\text { - Give subordinates greater or lesser freedom of action depending on their willingness to perform the task }\end{array}$ \\
\hline
\end{tabular}

Note: Adapted from Melo (2004). 
The theoretical bases of the EAEG are detailed below:

a) Relationship: deals with the scope that characterizes the relations established by the leader regarding mutual trust, friendship, warmth, respect for the ideas of subordinates, and concern for their feelings. Individuality and interpersonal relationships are valued by the leader. The theoretical bases that support this style are: consideration dimension of leader behavior (Likert, 1971); employeecentered supervision, studies at Michigan University (Likert, 1971); concern for employees, from the managerial grid of Blake and Mouton (1973); relationship orientation (Fiedler, 1967); leader behaviors termed consultative (Vroom \& Yetton, 1973);

b) Task: deals with the probability of the leader defining and structuring his/her role and that of his/her subordinates in the pursuit of achieving goals. The leader will emphasize aspects such as work, technical job issues, adherence to standards, communication channels, hierarchy, procedures and methods, and the accomplishment of tasks. The theoretical bases that support this style are: initial structure (Likert, 1971); servicefocused supervision, studies at Michigan University (Likert, 1971); concern for production/results, from the managerial grid of Blake and Mouton (1973); task orientation (Fiedler, 1967); leader behaviors termed autocratic (Vroom \& Yetton, 1973);

c) Situation: deals with the leader's ability to identify the reality of his/her work environment and adapt his/her style to the demands of that environment. The leader has the flexibility to adapt his/her behavior according to the needs and motives of his/ her subordinates. The theoretical basis for this approach refers to the situational leadership approach proposed by Hersey and Blanchard (1986), for which the appropriate leadership style depends on the level of employee maturity.

\section{Study Objective and Research Hypotheses}

The research carried out had the objective of identifying how managers' leadership styles influence the commitment of their teams. The literature served as the basis for hypotheses on the existence of relations between different styles of leadership and the type and level of commitment presented by those being led. From this perspective, we sought to determine if the relationship-oriented leadership style, which is characterized, among other things, by the valorization of interpersonal relationships and by respect for the ideas of team members (Melo, 2004), has a positive relation with affiliate commitment, in which the feeling of belonging and the expectation of being recognized by the work group predominates (Medeiros, 2003; Medeiros et al., 2005). Thus, the following hypothesis was formed:

H1: there is a positive relationship between the affiliate component of commitment and the relationship-oriented leadership style.

As the task-oriented leadership style has among its characteristics the emphasis on task execution, meeting deadlines, following established norms and rules, placing the work above all else (Melo, 2004), we sought to verify the existence of a positive relationship with the normative component. What predominates in this case are the moral commitment to the organization and the focus on performance, on results, and on the attainment of organizational objectives (Medeiros, 2003; Medeiros et al., 2005). Thus, the following hypothesis was formed:

H2: there is a positive relationship between the normative component and the taskoriented leadership style; 
With respect to the task-oriented leadership style, considering that respect for hierarchy, discipline, compliance with norms and deadlines, among others (Melo, 2004), being characteristic of this style, could be positively associated with instrumental commitment, in which predominate the desire to maintain one's job and the view that effort and reward are directly related (Medeiros, 2003; Medeiros et al., 2005), we sought to verify the following hypothesis:

H3: there is a positive relationship between the instrumental component and the taskoriented leadership style.

Given that the situational leadership style is the one in which the leader identifies the reality of his/her environment and adapts his/her style to its demands, considering, among other things, the level of maturity and the needs of those being led (Melo, 2004), we sought to verify the existence of a positive relation with affective commitment, in which the internalization of organizational values and objectives predominates (Medeiros, 2003; Medeiros et al., 2005). Thus, the following hypothesis was defined:

H4: there is a positive relationship between the affective component and the situational leadership style.

Furthermore, it was thought that higher levels of commitment could be positively related to the situational leadership style (Melo, 2004). Thus, the following hypothesis was defined:

H5: commitment is greater in respondents who classified the leadership style of their managers as situational.

Next, Figure 1 presents the hypotheses that guided this study:

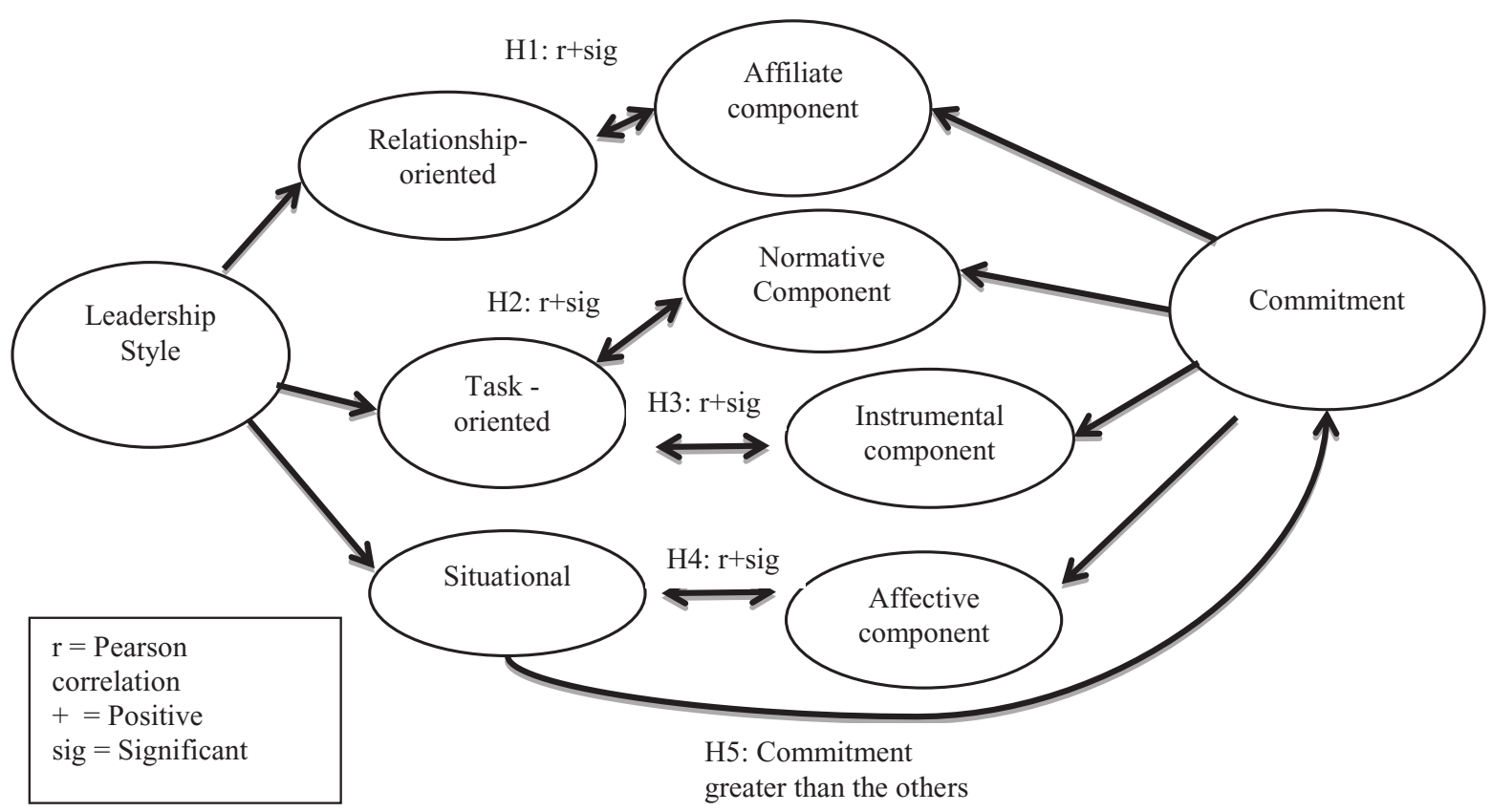

\section{Methodology}

This study took a quantitative strategy and adopted the survey as the research method. Two scales were used: the EBACO, developed and validated by Medeiros (2003) and that, in this study, aimed at ascertaining the level of commitment of those led; and the $E A E G$, constructed and validated by Melo (2004) and 
whose application in the present research was aimed at identifying the leadership style of managers. It is emphasized that, for the purposes of this study, the term leadership style will be used instead of managerial style, as it is in the EAEG. This was done considering the correspondence between the terms, since the EAEG was conceived based on studies that favored the use of the term leadership.

The $E B A C O$ was answered by means of a progressive 7-point Likert scale. The EAEG is composed of a 5-point scale, being: 1-never acts like this, 2-rarely acts like this, 3occasionally acts like this, 4-often acts like this, and 5-always acts like that.

The sample consisted of professionals who met the following criteria: employed during the data collection period and having a subordinate relationship with a manager. Participants could exercise a leadership role or not. They were professionals connected to the LinkedIn and Facebook relationship networks of one of the research team members, and who comprised a substantial number of professional contacts from different locations in the country. After identifying the professionals, an invitation to participate in the research was sent by e-mail, explaining the main objectives of the study. Then, the electronic questionnaires were also sent by e-mail to each of them, totaling 660 . The time allotted for data collection was three months.

The valid questionnaires totaled 587. On the minimum size of a sample, Gorsuch (1983) stated that it should contain at least five observations per variable, and a total sample of at least 200 observations. The final sample of the study meets this criterion.

Descriptive statistics and Chi-Square Automatic Interaction Detector (CHAID) analysis were used to evaluate the existence of significant differences between the constructs considered in the study and profile variables. This technique allows assessment of the relationship between a dependent variable and others at a categorical or continuous level. The resulting subsets present a greater homogeneity internally in relation to the dependent variable and with the greatest possible heterogeneity among the subsets formed. The division or grouping criteria used in this technique were set at $5 \%$, that is, the subsets had a significant difference when using the chisquare test (at the 5\% level). The profile variables used were age, marital status, have children, hold a leadership position, salary range, educational level, length of service, and if the current job is the respondent's first. Marital status and the current job being the first one did not present any significant result in this study. Thus, this article presents only the principal situations where a relationship exists between the profile variables and the dimensions studied.

For the purpose of proving the study hypotheses, the relationships were evaluated using the Pearson correlation between the scores obtained for the constructs involved.

The Pearson correlation coefficient ranges from -1 to 1 and indicates the degree and direction of the linear relationship (if any) between two variables. Values close to -1 indicate a high negative correlation, values close to zero indicate an absence of correlation, and values close to 1 indicate a high positive correlation.

Hypothesis testing was also done to verify if this correlation is significantly different from zero. As a response to the hypothesis test, the $p$-value is obtained. The difference was considered significant if the value was less than 0.05 . The interpretation of the correlation coefficient considered, according to Stevenson (1986): from 0 to 0.3 (low); more than 0.3 up to 0.7 (moderate); and more than 0.7 (high).

\section{Analysis and Discussion of Results}

\section{I Commitment: focus on those being led}

The main characteristics of the study sample, considering the highest results, were: males (66.8\%); married (73.8\%); have one child; 
40 years old; working for seven years in the current company; education to a specialization level (65.6\%); salary above 13 times minimum wage (45.5\%); hold a leadership position $(57.4 \%)$; working in the current company due to the opportunity for professional growth (77\%); and not in their first job (88.9\%).
In relation to the results obtained by from the $E B A C O$, in order to meet the objective of ascertaining the level of commitment of those led, Tables 3 and 4 present the results. The components of commitment were assessed on a scale ranging from 1 to 7 . Thus, the value 4 is the midpoint. Means above this point were considered high. Table 3 presents the results:

Table 3

\section{Components of commitment of team members: main results}

\begin{tabular}{|c|c|c|c|}
\hline Component & $\begin{array}{l}\text { Composite } \\
\text { Reliability }\end{array}$ & Mean & $\begin{array}{l}\text { Standard } \\
\text { Deviation }\end{array}$ \\
\hline Affiliate & 0.909 & 5.7 & 1.2 \\
\hline Affective & 0.935 & 5.0 & 1.4 \\
\hline Normative - general & 0.845 & 3.7 & 1.1 \\
\hline Normative - Obligation for Performance & 0.874 & 6.5 & 0.7 \\
\hline Normative - Obligation to Stay & 0.946 & 3.1 & 1.7 \\
\hline Instrumental - general & 0.803 & 3.4 & 1.1 \\
\hline Instrumental - Consistent Line of Activities & 0.869 & 4.7 & 1.4 \\
\hline Instrumental - Limited Alternatives & 0.802 & 3.4 & 1.6 \\
\hline Instrumental - Failure of Rewards and Opportunities & 0.810 & 2.7 & 1.4 \\
\hline Commitment of those led & 0.694 & 5.4 & 1.1 \\
\hline
\end{tabular}

Internal consistency was assessed through composite reliability (Table 3 ). For all constructs, the value obtained is above the threshold of 0.7 proposed by Chin (1998), with the exception of the construct, Commitment of those led, with a value very close to that level (0.694).

The overall commitment of those led is considered high among respondents, since the mean (5.4) is above the midpoint of the scale. Among its components, the affiliate and the affective can be considered high, since their means (5.7 and 5.0, respectively) are above the midpoint. The normative (general) and instrumental (general) components can be considered moderate among the respondents (3.7 and 3.4, respectively), however, normative-obligation for performance is considered high (mean equal to 6.5). This result suggests that, although the respondents have a moderate sense of obligation to remain in the organization and also moderate commitment due to the scarcity of alternatives in the labor market, they prove to be committed to the organization's objectives and results.

Table 4 shows the results of the correlation between commitment and the profile of the respondents. In order to carry out this analysis, the general results of the normative and instrumental component were used, as follows: 
Table 4

Commitment of those led and profile of the respondents

\begin{tabular}{|c|c|c|}
\hline Component & Principal Significant Differences * & Means \\
\hline \multirow{3}{*}{ Affiliate } & Greater in leadership positions & 5.769 \\
\hline & Greater in those with more than 16 years of work in the current organization & 6.062 \\
\hline & Greater in males & 5.744 \\
\hline \multirow{4}{*}{ Affective } & Greater in leadership positions & 5.154 \\
\hline & Less in ages between 30 and 35 years & 4.631 \\
\hline & Greater in those with more than 16 years of work in the current organization & 5.647 \\
\hline & Greater in those with children & 5.188 \\
\hline \multirow{4}{*}{ Normative } & Greater in leadership positions & 3.848 \\
\hline & Greater for those over 46 years old & 3.929 \\
\hline & Greater in males & 3.763 \\
\hline & Greater in those with children & 3.781 \\
\hline \multirow{2}{*}{ Instrumental } & Less in leadership positions & 3.224 \\
\hline & Greater for those with up to seven times minimum wage & 3.544 \\
\hline \multirow{4}{*}{ General Commitment } & Less for those under 33 years old & 5.188 \\
\hline & Greater in those with more than 16 years of work in the current organization & 5.842 \\
\hline & Greater in males & 5.483 \\
\hline & Greater in those with children & 5.503 \\
\hline
\end{tabular}

* Note: The differences between means were considered significant at the $5 \%$ level of significance in the CHAID test.

In the affiliate component, the highest mean is for men (5.744) and those with leadership positions (5.769). In addition, the longer the time working in the current organization (above 16 years) (6.062), the higher the level of affiliate commitment.

The affective component presents a higher mean among those with leadership positions (5.154). A study by Yoshitake, Fraga, Torres and Passos (2009) found an inverse result. In the case of affective commitment, these authors verified that the mean of this component, in operational positions, was statistically different from the mean for leadership positions. That is, employees who do not hold a leadership position prove to be more affectively committed to the company than those who occupy that position.

A lower mean in relation to the affective component was found in individuals between the ages of 30 and 35 (4.631), i.e., Generation Y, born between 1981 and 2000 (Zemke, Raines, \& Filipczak, 2000). The explanation for this result may lie in the fact that this is a generation, raised in the age of constant changes, that tends to have expectations of rapid career advancement, which drives the people in this group to change their organization. Generally speaking, if people of this generation do not feel that there is opportunity to contribute and to be recognized in the short term, they will probably go look for it in another organization. (Tanure, Carvalho, \& Andrade, 2007). Considering that the affective component refers to the process of the individual identifying with the objectives and the values of the organization, the lower result in the respondents belonging to this generation is warranted. Still, individuals with children presented a higher mean (5.188) for the affective component, as well as those with more time working in the current organization (5.647).

Normative commitment is greater in men (3.763), in people who occupy a leadership role (3.848), in those who have children (3.781), and who are over 46 years old (3.929). Considering this last result for people over 56 years of age, the baby boomer generation age group, some observations can be made. The so-called Baby Boomers follow the traditional values related to fulfilling their obligations regarding career, loyalty to the organization, education and raising of children, marriage, among others. In addition, they tend to be more cooperative and 
participative at work. They are inclined to be loyal to their organizations, cooperative, and to build their identities based on their work (Zemke et al., 2000). A study by Martins (2013) also shows that normative commitment is greater in the more advanced age groups.

Compared to the other components, the instrumental attained the lowest mean (3.4). According to Rego, Cunha and Souto (2007), when the strongest link is the instrumental one, employees usually do not give the organization anything more than they are obligated and it can lead them to adopt negative attitudes and actions. Therefore, the lowest level of this kind of commitment found in the research can be translated as an advantage to the organizations where these respondents work.

The instrumental component presents a significant difference with respect to holding a leadership position or not, being greater among those who do not have a leadership role (3.224). A similar result was found in the study by Costa, Moraes and Cançado (2008), in which the instrumental component presented a significant difference on this question as well, with those who do not occupy a leadership position showing greater instrumental commitment, presenting higher means than the rest.

Moreover, the instrumental component is related to salary numbers. The greatest mean is presented among individuals receiving up to seven times the minimum wage (3.544). It can be said that a respondent who receives up to seven times the minimum wage has lower qualifications than those who receive higher salaries. Medeiros (2003) indicates the employee with this type of commitment as the one with low qualifications, few alternatives if he/she leaves the organization and, as Meyer and Allen (1991) affirm, remains in the company because he/she needs to. Although the sample in this study has at least a university degree, it is possible to infer that, due to the salary profile, these respondents may not be occupying a position commensurate with their training.

The mean for the commitment construct is greater among males (5.483). This result is in agreement with Akintayo (2010), but in disagreement with Porter and Steers (1982), according to whom commitment tends to be greater among women, especially among those who are married. It also contrasts with the study by Sangmook (2005), which indicates that women, compared to men, present higher levels of involvement in their employment. In addition, several studies (AI-Ajmi, 2006, Suki, \& Suki, 2011, Suri, \& Petchsawang, 2018) concluded that men and women have the same level of organizational commitment, which differs from the findings of the present research.

The construct presents a relationship with age - the lowest mean appears among individuals age 33 or less (5.188). This result corroborates the study by Bandeira (1999), which states that committed individuals are represented by older people, over 35 years of age, who know their expectations. Also, other authors have found results that show that commitment increases with age, such as Bastos (1993), Nawaz and Kundi (2010), Honório and Ribeiro (2014), and Suri and Petchsawang (2018).

People with children also show a positive relation with the commitment construct, with the mean they present being greater (5.503). This result can be corroborated by Martins (2013), who found greater commitment in those with up to two children. Nevertheless, there is research showing that the increase in the number of children leads to a reduction in the level of commitment (Chang, 2001, Akintayo, 2010).

Moreover, the longer the time working in the current organization, the higher the level of commitment (5.842). In agreement with Suri and Petchsawang (2018), it is inferred that respondents have gained experience and have progressed in their career within the company, which leads to a higher level of commitment. The result, however, contrasts with the study by Honório and Ribeiro (2014), in which teachers who worked for less than six years in the institution showed greater commitment. 


\section{2 Leadership Styles: focus on managers}

Table 5 presents the results of administering the $E A E G$, which sought to identify leadership styles. Also shown are the results of the correlations between leadership style and the profile of the respondents (those led). With the value 3 being the midpoint on the scale, means above 3 were considered high.

Table 5

\section{Principal results found in the research on leadership style}

\begin{tabular}{|l|c|l|c|}
\hline Leadership style & Mean Result & Principal Significant Differences * & Mean \\
\hline Relationship-oriented & 3.8 & $\begin{array}{l}\text { Greater in leadership positions } \\
\text { Greater in those over 46 years old } \\
\text { Greater for those with more than one child }\end{array}$ & 3.913 \\
& & & 3.021 \\
& & Greater in males & 384 \\
\hline Task-oriented & 3.9 & Greater in those over 46 years old & 3.963 \\
& & Greater for those with at least one child & 3.988 \\
\hline Situational & 3.9 & Greater in leadership positions & 3.989 \\
& & Greater in males & 4.046 \\
& & Greater for those with more than one child & 4.101 \\
\hline
\end{tabular}

* Note: The differences between means were considered significant at the $5 \%$ level of significance in the CHAID test.

The relationship-oriented leadership style mean was 3.8 . In relation to the sample of respondents (those led), the following results predominated regarding the choice of the relationship-oriented style, with higher mean values than the rest: those who work in a leadership position (3.913); individuals over 46 years of age (4.021); people with more than one child (3.984).

This result indicates that the leader is seen by his/her team members as one who values individuality and emphasizes interpersonal relationships with respect to support, guidance, and facilitation. The leader demonstrates readiness to listen to team members, pays attention to them, cares about what they feel, respects their ideas, is understanding about their failures, encourages open expression about the development of their work, and demonstrates confidence in his/her subordinates. Included under the designation of this leadership style are the types known as "democratic, participatory, stimulating, supportive, and the style of those who give consideration" (Melo, 2014, p.39).

The task-oriented leadership style mean was 3.9. In relation to the sample of respondents (those led), the following results predominated regarding the choice of the task-oriented style, with higher mean values than the rest: males (3.963); individuals over 46 years of age (4.055); those with at least one child $(3,988)$.

This result shows that team members see their leader as one who values the hierarchy, emphasizes meeting deadlines, prioritizes the execution of tasks and their structuring, as well as considers the standards defined by the leadership and/or organization. Included under the designation of this leadership style are the types "authoritarian, dominant, directive, autocratic, and persuasive" (Melo, 2014, p. 39).

The situational leadership style presented a mean of 3.9. In relation to the sample of respondents (those led), the following results predominated regarding the choice of the situational style, with higher mean values than the rest: males (3.989); leadership position (4.046); have more than one child (4.101).

This result shows that the leader is perceived as one who is flexible in dealing with the team members, "giving them greater or lesser freedom of action, depending on their reliability, 
competence, motivation, and willingness to carry out their work" (Melo, 2014, p. 58). Thus, the leader acts according to the level of maturity of the team members, as advocated by Hersey and Blanchard (1986).

Melo (2014) recalls that situational leadership is based on an interrelationship between: the behavior of the task-oriented leader; the behavior of the relationship-oriented leader; and the capacity and willingness of subordinates to perform the tasks (maturity). Thus, for situational leadership, there is no single best way to influence people.

\subsection{Leadership styles and organizational commitment: analyzing hypotheses}

The analysis of the correlation between the commitment of team members and the leadership style of managers was done using hypothesis tests, through which $p$-values were obtained. $P$-values less than 0.05 indicate a significant difference. The correlation results and the $p$-values (Table 6) follow:

Table 6

\section{Correlations between leadership styles and commitment constructs}

\begin{tabular}{lcccccc}
\hline & \multicolumn{2}{c}{ Relationship } & \multicolumn{2}{c}{ Situational } & & Task \\
\cline { 2 - 6 } & Correlation & p-value & Correlation & p-value & Correlation & p-value \\
\hline Commitment of Those Led & 0.484 & 0.000 & 0.411 & 0.000 & 0.320 & 0.000 \\
\hline Affective & 0.439 & 0.000 & 0.336 & 0.000 & 0.280 & 0.000 \\
\hline Affiliate & 0.461 & 0.000 & 0.436 & 0.000 & 0.310 & 0.000 \\
\hline Instrumental & -0.148 & 0.000 & -0.082 & 0.048 & -0.020 & 0.631 \\
\hline $\begin{array}{l}\text { Instrumental - Consistent Lines of } \\
\text { Activity }\end{array}$ & 0.202 & 0.000 & 0.207 & 0.000 & 0.255 & 0.000 \\
\hline $\begin{array}{l}\text { Instrumental - Rewards and } \\
\text { Opportunities }\end{array}$ & -0.266 & 0.000 & -0.184 & 0.000 & -0.138 \\
\hline $\begin{array}{l}\text { Instrumental - Limited Alternatives } \\
\text { Normative }\end{array}$ & -0.119 & 0.004 & -0.074 & 0.074 & -0.029 \\
\hline Normative - Obligation to Stay & 0.475 & 0.000 & 0.405 & 0.000 & 0.307 & 0.486 \\
\hline $\begin{array}{l}\text { Normative - Obligation for } \\
\text { Performance }\end{array}$ & 0.213 & 0.000 & 0.187 & 0.000 & 0.150 \\
\hline
\end{tabular}

The results in Table 6 show that there is a significant correlation between the overall commitment of team members and the three leadership styles. These correlations are considered moderate, since the values were between 0.3 and 0.7 for a $p$-value equal to 0.000 . These are also moderate: the correlations between affective commitment and the relationship and situational leadership styles; between the affiliate component and the three styles; and between the normative component and the three leadership styles. For the remaining components of commitment, the correlations were weak or nonexistent. Next, the results are presented regarding the hypotheses formed for this study.
For $\mathrm{H} 1$, the value found is equal to 0.461 . This result indicates positive correlation, so when the assessment of the relationship-oriented leadership style increases, the magnitude of the affiliate component of commitment increases, and vice versa, when one decreases, the other also decreases, confirming the hypothesis.

The confirmation of $\mathrm{H} 1$ leads us to infer that a leadership style that values interpersonal relationships, respects the ideas of those being led, seeks to establish a relationship of trust, and that shows interest in the feelings of those being led, characteristic of the relationship-oriented style (Melo, 2004), generates in those being led the feeling of recognition and belonging, associated 
with the affiliate component (Medeiros, 2003; Medeiros et al., 2005).

In the case of $\mathrm{H} 2$ and $\mathrm{H} 3$, both testing the task-oriented style, the results are:

a) H2: the value found is equal to 0.307 . This indicates positive correlation: when the assessment of the task-oriented style increases, the magnitude of the normative component increases, and vice versa, confirming the hypothesis.

b) H3: the instrumental component and the task-oriented style did not show a significant correlation, with a $p$-value equal to 0.631 , not confirming the hypothesis.

The adoption of a leadership style that emphasizes task execution, in which the leader defines and structures the role of his/her team members, is concerned with production and results, being characteristics of the task-oriented style (Melo, 2004), as presented in H2, leads us to infer, on the one hand, that such a style can generate a sense of obligation for performance in the team members, seeking to complete their tasks and do their jobs well in pursuit of company objectives, associated with the normative component (Medeiros, 2003; Medeiros et al., 2005). On the other hand, the adoption of the task-oriented style, also tested in $\mathrm{H} 3$ - unconfirmed - allows us to infer that the team members do not feel connected to the organization simply because of the scarcity or absence of other job opportunities on the outside, or even that they just act with a view that there must be a clear correspondence between effort and reward, characteristics that are associated with the instrumental component.

In the case of $\mathrm{H} 4$ and $\mathrm{H} 5$, both testing the situational style, we have the results:

a) H4: a value equal to 0.336 was found. This result indicates positive correlation, that is, when the assessment of the situational leadership style increases, the magnitude of the affective component of commitment increases, and vice versa, confirming the hypothesis.

b) $\mathrm{H} 5$ : the value found is equal to 0.411 . This indicates positive correlation, and when the assessment of the situational style increases, general commitment increases, and vice versa, when one decreases, the other also decreases, confirming the hypothesis.

These results lead us to infer that, when the leader adapts his/her style to the reality of the environment, being flexible according to the needs and the level of maturity of those being led, characteristic of the situational style (Melo, 2004), this allows those being led to identify with the objectives and values of the organization, and generates positive feelings in them, who find an environment of support (Royal, 2012), encouraging involvement, and thus, commitment.

\section{Final Considerations}

The study sought to contribute to the discussions on the topic of organizational commitment and leadership, looking to explore the relationships between leadership styles of managers and the commitment of those they lead. The following are aspects suggested by the study.

There is a positive relationship between relationship-oriented leadership style and the affiliate component of commitment of team members. Considering that the relationshiporiented style refers to the extent to which the relationships between leader and team member are characterized by the leader's respect for the ideas of his/her subordinates and the demonstration of interest in their feelings, the affiliate commitment of the team member is warranted, because it refers to the feeling of taking part, of being a member of the work team.

There is a positive relationship between the task-oriented style and the normative component. Since the task-oriented style refers to the emphasis the leader places on structuring tasks and accomplishing goals, the normative commitment of the team member is warranted. This is because this component of commitment takes into account the existence of a sense of obligation to accomplish the tasks, to show good job performance, and to attempt to achieve the best results.

There is a positive relationship between the situational style and affective commitment, as 
well as between this style and overall commitment. This result points to the adaptation of the leader's style to the demands of the environment, showing that the flexibility to adapt to the needs and motives of his/her subordinates has a positive effect on their commitment, generating, among other things, the subordinate's identification with the philosophy of the organization .

In this study, we highlight some other results, such as: relationship between the affective and normative components and the relationshiporiented leadership style; and relationship between the affiliate and normative components and the situational style. These results showed positive and moderate correlations. It is worth mentioning that all correlations between all the components of commitment and the task-oriented leadership style were low or not significant.

This study contributes to the debate about the existence of a relationship between some components of commitment and leadership styles, pointing out how leadership style can affect the type of commitment of team members with the organization, specifically regarding the positive relationship between the situational style and general commitment; the relationship-oriented style and the affiliate component; and the taskoriented style and the normative component.

The present study suggests that new studies should be carried out in order to confirm some of the results considered significant. Examples are: relationship between the organizational commitment and leadership constructs, with a focus on commitment and the relationship style; and the relationship between commitment and aspects of respondent profiles regarding gender and generation. These are results that were encountered and that allow us to delineate hypotheses for other studies. It should also be considered that some factors constitute study limitations, such as the size of the sample surveyed, although it is sufficient from a statistical point of view; the strategy of collecting data of an exclusively quantitative nature, limiting the possibility of finding answers not provided for in the chosen scales; and the non-delimitation of sector, region of the country, or a profession, meaning that the findings are to be considered generic.

\section{References}

AI-Ajmi, R. (2006). The effect of gender on job satisfaction and organizational commitment in Kuwait. International Journal of Management, 23(4), 838-844.

Akintayo, D. I. (2010). Work-family role conflict and organizational commitment among industrial workers in Nigeria. Journal of Psychology and Counseling, 2(1), 1-8.

Balci, A. (2003). Örgütsel sosyallesme kuram strateji ve taktikler. Ankara: Pegem A Yayincilik. Journal of Business Research, 26(1), 63-73.

Bandeira, M. L. (1999). Investigando o impacto das politicas de recursos humanos no comportamento organizacional em uma empresa de serviços do setor público. (Dissertação de mestrado, Universidade Federal de Minas Gerais, 1999).

Bass, B. M. (2008). The Bass handbook of leadership: theory, research, and managerial applications. (4th ed.). New York: The Free Press.

Bastos, A. V. B. (1993). Comprometimento organizacional: um balanço dos resultados e desafios que cercam essa tradição de pesquisa. Revista de Administração de Empresas, 33(3), 52-64.

Blake, R., \& Mouton, J. S. (1973). O grid gerencial. São Paulo: Pioneira.

Borges-Andrade, J. E., Cameschi, C. E., \& Silva, M.S. (1990). Comprometimento organizacional em instituiçôes de pesquisa: diferença entre meio e fim. Revista de Administração, 25(4), 9-43.

Bycio, P.; Hackett, R. D., \& Allen, J. S. (1995). Further assessments of Bass's conceptualization of transactional and transformational leadership. Journal of Applied Psychology, 4(80), 468-478.

Cappi, M. N., \& Araújo, B. F. v. B. (2015). Satisfação no trabalho, comprometimento organizacional e intenção de sair: um estudo entre as geraçóes X e Y. Revista Eletrônica de Administração, 21(3), 576-600. 
Cardozo, B. D. A., Araújo, G. C., \& Silva, C. R. (2015). Comprometimento organizacional e gestão de bens materiais e patrimoniais em um empreendimento econômico solidário: um estudo em uma cooperativa de reciclagem. Revista de Administração Mackenzie, 16(4), 15-42.

Chang, J. (2001). Gestão de pessoas pelo desenvolvimento do comportamento organizacional: uma abordagem holistica e simultânea. (Tese de Doutorado, Universidade de São Paulo, 2001).

Chin, W. W. (1998). The partial least squares approach to structural equation modeling. In: Marcoulides, G. A. (Ed.). Modern methods for business research. USA: Lawrence Erlbaum Associates, Inc.

Colbert, A. E., Barrick, M. R., \& Bradley, B. H. (2014). Personality and leadership composition in top management teams: implications for organizational effectiveness. Personnel Psychology, 67, 351-387.

Cole, M.S., Walter F ., Bedeian A.G. \& O’Boyle E.H. (2012). Job burnout and employee engagement: A meta-analytic examination of construct proliferation. Journal of Management, $38,1550-1581$.

Costa, C., Moraes, L. F., \& Cançado, V. (2008). Avaliando o Comprometimento Organizacional e Possíveis Relaçôes com o Turnover. Revista Gestão \& Tecnologia, 8(2), 1-16.

Delfino, A. L., Silva, A. B., \& Rohde, L. R. (2010). A produção acadêmica sobre liderança no Brasil: uma análise bibliométrica dos artigos publicados em eventos e periódicos entre 1995 e 2009. In: Anais Encontro Anual da ANPAD. Rio de Janeiro.

Fernandes, C. M., Siqueira, M. M. M., \& Vieira, A. M. (2014). Impacto da percepção de suporte organizacional sobre o comprometimento organizacional afetivo: o papel moderador da liderança. Revista Pensamento Contemporâneo em Administração, 8(4), 140-162.
Fiedler, F. E. (1967). A theory of leadership effectiveness. New York: McGraw-Hill.

Gilbert, D ., Halliday, S., Heavey, C \& Murphy, E. (2011). Enhancing performance Bringing trust, commitment and motivation together in organizations. Journal of General Management, 36(3), 1-18.

Gorsuch, R. L. (1983). Facto analysis. Hillsdale, NJ: Erlbaum.

Hersey, P., \& Blanchard, K. (1986). Psicologia para administradores: a teoria e as técnicas da liderança situacional. São Paulo: E.P.U.

Honório, L. C., \& Ribeiro, J. G., Filho. (2014). Comprometimento Organizacional: Comparando Docentes Efetivos e Temporários de uma Instituição de Ensino Superior. Organizaçóes em contexto, 10(20), 173-204.

Iqbal, J., Inayat, S., Ijaz, M., \& Zahid, A. (2012). Leadership styles: Identifying approaches and dimensions of leaders. Interdisciplinary Journal of Contemporary Research in Business, 4(3), 641-659.

Khan, I., Khan, F., Khan, H., Nawaz, A., \& Yar, N. B. (2013). Determining the Demographic impacts on the Organizational Commitment of Academicians in the HEIs of DCs like Pakistan. European Journal of Sustainable Development, 2(4), 117-130.

Leite, N.R. P. (2008). Comprometimento e Gestão de Pessoas em Empresas Brasileiras com estruturas organizacionais remotas. (Tese de Doutorado). Universidade de São Paulo, São Paulo.

Leite, N.R.P. \& Albuquerque, L.G. (2011). Gestão Estratégica de Pessoas, comprometimento e contrato psicológico: o caso Vale. Revista de Administração., 46(1), 19-31, São Paulo.

Lemos, A. H. C., Cavazotte, F. S. C. N., \& Nogueira, A. S. (2012). Geraçóes produtivas e comprometimento organizacional: um estudo comparativo com oficiais da aeronáutica. Revista Gestão \& Planejamento, 13( 3), 694-711. 
Likert, R. (1971). New patterns of management. New York: McGraw-Hill.

Maciel, C. O., \& Nascimento, M. R. (2013). Em busca de uma abordagem não atomizada para o exame das relaçôes entre liderança transformacional e comprometimento organizacional. Revista de Administração, 48(3), 544-559.

Marques, A. L., Borges, R., Morais, K., \& Silva, M. C. (2014). Relaçôes entre resistência à mudança e comprometimento organizacional em servidores públicos de Minas Gerais. Revista de Administração Contemporânea, 18(2), 161-175.

Marques, G. M., Medeiros, C. A. F., França, A. G. C., \& Ribeiro, M. F. G. (2007). Estilos de liderança e comprometimento organizacional: uma aplicação do Multifactor Leadership Questionnaire (MLQ) no Brasil. Revista ADM. MADE, 11(2), 99-125.

Martins, S. (2013). Valores individuais e comprometimento organizacional em burocracia profissional: um estudo com o corpo docente de instituição de ensino superior. (Dissertação de mestrado, Pontifícia Universidade Católica de Minas Gerais, 2013).

Medeiros, C. A. F., Albuquerque, L. G., Marques, G. M., \& Siqueira, M.. (2005). Um estudo exploratório dos múltiplos componentes do comprometimento organizacional. Revista Eletrônica de Administração, 1(11), 1-22.

Medeiros, C. A. F. (2003). Comprometimento organizacional: um estudo de suas relaçôes com características organizacionais e desempenho nas empresas hoteleiras. (Tese de doutorado, Universidade de São Paulo, 2003).

Mehta, S., \& Maheshwari, G. C. (2013). Consequence of Toxic leadership on Employee Job Satisfaction and Organizational Commitment. The Journal Contemporary Management Research, $8(2), 1-23$.

Melo, E. (2004). Escala de Avaliação do estilo gerencial (EAEG): desenvolvimento e validação.
Revista Psicologia: Organizaçóes e Trabalho, 4(2), 31-62.

Meyer, J. P., \& Allen, N.J. (1991). A three: component conceptualization of organizational commitment. Human Resource Management Review. 1(1), 61-89.

Meyer, J. P., Allen, N. J., \& Smith, C. A. (1993). Commitment to organizations and occupations: extension and test of a threecomponent conceptualization. Journal of Applied Psychology, 78(4), 538-551.

Meyer, J. P., Stanley, D. J., Herscovitch, L., \& Topolnytsky, L. (2002). Affective, continuance, and normative commitment to the organization: a meta-analysis of antecedents, correlates, and consequences. Journal of Vocational Behavior, 61(1), 20-52.

Moss, S.A., McFarland, J., Ngu, S., \& Kijowska, A. (2007). Maintaining an open mind to closed individuals: The effect of resource availability and leadership style on the association between openness to experience and organizational commitment. Journal of Research in Personality, 41, 259-275.

Mowday, R. T., Porter, L. W., \& Steers, R. M. (1982). Employee - organization linkages: the psychology of commitment, absenteeism and turnover. New York: Academic Press.

Naqvi, S.A.H., Hashmi, M.A., Raza, S.A., Zeeshan, A. \& Shaikh, F.F. (2011). Impact of Supportive Leadership and Organizational Learning Culture as a Moderator On The Relationship of Psychological Empowerment and Organizational Commitment. Australian Journal of Business and Management Research, 1(8), 65-71.

Nawaz, A., \& Kundi, G. M. (2010). Demographic implications for the user-perceptions of e-learning in higher education institutions of n-w.f.p, Pakistan. The Electronic Journal on Information Systems in Developing Countries, 41(5), 1-17.

Nogueira, M. L. O., Costa, L. V., \& Claro, J. A. C. D. S. (2015). Relação entre estilo de liderança e 
comprometimento organizacional afetivo. RACE: Revista de Administração, Contabilidade e Economia, 14(2), 707-736.

Oliveira, M. J. L., Cabral, A. C. A., Pessoa, M. N. M., Santos, S. M. , \& Roldan, V. P. S. (2014). Comprometimento organizacional e regime de remuneração: estudo em uma Carreira Pública de Auditoria Fiscal. Revista de Administração Mackenzie, 15( 5), 72-101.

O’Reilly, C. A., \& Chatman, J. (1986). Organizational commitment and psychological attachment: the effects of compliance, identification, and internalization on prosocial behavior. Journal of Applied Psychology, 71(3), 492-499.

Rayner, C. \& Cooper, C. (1997). Workplace bullying: myth or reality - can we afford to ignore it? Leadership and Organization Development Journal, 18, 211-214.

Rego, A., Cunha, M. P., \& Souto, S. (2007). Espiritualidade nas organizaçóes e comprometimento organizacional. $R A E$ eletrônica, 6(2).

Ricco, M. F. (1998). Comprometimento organizacional em condiçóes adversas: o caso dos pesquisadores do Centro Técnico Aeroespacial. (Dissertação de mestrado, Universidade de Sáo Paulo, 1998).

Royal, M. (2012). O inimigo do engajamento profissional: conquiste o comprometimento de sua equipe e elimine a frustração corporativa. Rio de Janeiro: Elsevier.

Sá, M. A. D. \& Lemoine, C. (1998). O estilo de liderança como fator de comprometimento na empresa. In: Anais Encontro Anual da ANPAD. Foz do Iguaçu.

Saher, N., Naz, S., Tasleem, I, Naz, R, \& Kausar, S. (2013). Does paternalistic leadership lead to commitment? trust in leader as moderator in Pakistani context. Interdisciplinary Journal of Contemporary Research in Business, 5(1), 443-455.
Sangmook, K. (2005). Sex differences in the professional satisfaction of the public officers: a study Metropolitan Government of Seoul, Korea. The Journal of Research, May.

Seong, J. Y., Hong, D.-S., \& Park, W.-W. (2012). Work status, gender, and organizational commitment among Korean workers: the mediating role of person-organization fit. Asia Pacific Journal of Management, 29, 1105-1129.

Silva, C. C., Leite, N. R. P., \& Rodrigues, L. C. (2016). Gestão estratégica de pessoas e comprometimento organizacional em organizaçóes hospitalares. Revista de Administraçâo da UFSM, 9(2), 192-209.

Steil, A. V., Penha, M. M., \& Bonilla, M. A. M. (2016). Antecedentes da retenção de pessoas em organizaçôes: uma revisão de literatura. Revista Psicologia: Organizaçôes e Trabalho, 16(1), p. 88-102.

Stevenson, W. (1986). Estatística aplicada à administração. São Paulo: Harper \& Row do Brasil.

Suki, N. M, \& Suki, N. M. (2011). Job satisfaction and organisational commitment: the effect of gender. International Journal of Psychology Research, 6(5), 1-15.

Suri, M., \& Petchsawang, P. (2018). Relationship between job satisfaction, organizational commitment and demographic factors in private banking sector in Bangkok. International Journal of Business \& Economics, 10(2), 167-189.

Tanure, B., Carvalho, A., Neto, \& Andrade, J. (2007). Executivo: sucesso e (in)felicidade. Rio de Janeiro: Elsevier.

Tushman, M. L., \& Nadler, D. A. (1986). Organizing for innovation. California Management Review, 8(3), 74-92.

Vroom, V. H., \& Yetton, P. W. (1973). Leadership and decision making. Pittsburgh: University of Pittsburgh Press.

Weaver, S.G., \& Yancey, G.B. (2010). The Impact of Dark Leadership on Organizational 
Commitment and Turnover. Kravis Leadership Institute, Leadership Review, 10, 104-124.

Webb, K.S. (2011). Emotional Intelligence and Worker Commitment: The Impact of Leaders Behavior on Employee Commitment to Their Supervisor and the Organization. Advancement of Management and International Business Conference Proceedings.

Yoshitake, M., Fraga, M., Torres, G., \& Passo, E. (2009). Controle de gestão: a aplicabilidade do modelo das três dimensões na investigação de níveis e tipos de comprometimento do capital humano nas organizações terceirizadas. Revista de Educação e Pesquisa em Contabilidade, 3(3), 39-61.
Yozgat, U.; Serim, R., \& Dikmen, D. (2014). Out of sight out of mind: effect of ostrich leadership on affective commitment and the moderating role trust in supervisor. Business Studies Journal, 6(1), 79-89.

Zanini, M. T. F., Santos, M. C. C. D., \& Lima, D. F. P. (2015). A influência do estilo de liderança consultivo nas relaçóes de confiança e comprometimento no Batalhão de Operações Policiais Especiais do Rio de Janeiro. Revista de Administração, 50(1), 105-120.

Zemke, R., Raines, C., \& Filipczak, B. (2000). Generations at work: managing the clash of veterans, boomers, xers, and nexters in your workplace. Nova York: AMACOM.

\section{About the Authors:}

1. Priscila Lopes da Silva, Mestre em Administração, Pontifícia Universidade Católica de Minas Gerais, Programa de Pós-Graduação em Administração, Belo Horizonte, Brasil. E-mail: priscilalsilva@ig.com.br ORCIID

(iD) 0000-0001-7081-1851

2. Simone Costa Nunes, Doutora em Administração, Universidade Federal de Minas Gerais, Centro de Pós-Graduação e Pesquisas em Administração, Belo Horizonte, Brasil. E-mail: sinunes@pucminas.br ORCIID

(iD) 0000-0002-7573-7985

3. Darly Fernando Andrade, Doutor em Administração, Universidade FUMEC, Belo Horizonte, Brasil. E-mail: darly@ufu.br

ORCIID

(D) 0000-0002-0615-9851

\section{Contribution of each author}

\begin{tabular}{|c|c|c|c|}
\hline Contribution & $\begin{array}{c}\text { Priscila Lopes da } \\
\text { Silva }\end{array}$ & $\begin{array}{c}\text { Simone Costa } \\
\text { Nunes }\end{array}$ & $\begin{array}{c}\text { Darly Fernando } \\
\text { Andrade }\end{array}$ \\
\hline 1. Definition of research problem & $\sqrt{ }$ & $\sqrt{ }$ & \\
\hline 2. Development of hypotheses or research questions ( empirical studies ) & $\sqrt{ }$ & $\sqrt{ }$ & $\sqrt{ }$ \\
\hline 3. Development of theoretical propositions (theoretical Work ) & n.a. & n.a. & n.a. \\
\hline 4. Theoretical foundation/ Literature review & $\sqrt{ }$ & $\sqrt{ }$ & \\
\hline 5. Definition of methodological procedures & $\sqrt{ }$ & $\sqrt{ }$ & $\sqrt{ }$ \\
\hline 6. Data collection & $\sqrt{ }$ & & $\sqrt{ }$ \\
\hline 7. Statistical analysis & & & $\sqrt{ }$ \\
\hline 8. Analysis and interpretation of data & $\sqrt{ }$ & $\sqrt{ }$ & $\sqrt{ }$ \\
\hline 9. Critical revision of the manuscript & & $\sqrt{ }$ & $\sqrt{ }$ \\
\hline 10. Manuscript Writing & $\sqrt{ }$ & $\sqrt{ }$ & $\sqrt{ }$ \\
\hline
\end{tabular}

